www.jmscr.igmpublication.org

Impact Factor 5.244

Index Copernicus Value: 83.27

ISSN (e)-2347-176x ISSN (p) 2455-0450

crossref DOI:_http://dx.doi.org/10.18535/jmscr/v4i8.63

\title{
Solitary Plasmacytoma of Scalp without Intra Cranial Extension- A Cytological Rare Case Report
}

\author{
Authors \\ Dr Poonam Woike ${ }^{1}$, Dr Sudha Iyengar ${ }^{2}$, Dr Arun Jain ${ }^{3}$, Dr Bhavna Karnwal ${ }^{4}$, \\ Dr Rajesh Gaur ${ }^{5}$ \\ ${ }^{1}$ Post Graduate Student, Department Of Pathology, G.R Medical College, Gwalior, M.P, India \\ ${ }^{2}$ Associate Professor, Department Of Pathology, G.R Medical College, Gwalior M.P, India \\ ${ }^{3}$ Assistant Professor, Department Of Pathology, G.R Medical College, Gwalior M.P, India \\ ${ }^{4}$ Post Graduate Student, Department Of Pathology, G.R Medical College, Gwalior, M.P, India \\ ${ }^{5}$ Professor \& Head, Department Of Pathology, G.R Medical College, Gwalior, M.P, India \\ Corresponding Author \\ Dr Poonam Woike
}

Department of Pathology, G.R Medical College, Gwalior, M.P, India

Phone No- 7745983670

\begin{abstract}
In this report we present an interesting rare case of solitary plasmacytoma of the scalp without bony erosion in a 52 year female. The clinicians suspected it to be a malignant tumor, but didn't come to a conclusion as the radiological and clinical findings were not very useful. Hence, the patient was sent to the cytopathology section of Department Of Pathology to pursuit a diagnosis. Fine needle aspiration cytology (FNAC) was used as the first line of investigation in this case.
\end{abstract}

Key words- Extramedullary Plasmacytoma, Fine Needle Aspiration Cytology.

\section{Introduction}

Plasma cell neoplasms represent a spectrum of diseases characterized by clonal proliferation and accumulation of immunoglobulin-producing terminally differentiated B-cells. In 2003, the International Myeloma Working Group published criteria for the classification of monoclonal gammopathies, multiple myeloma and related disorders recognizing solitary plasmacytoma (SP) of bone, extra-medullary plasmacytoma and multiple Solitary Plasmacytoma ( \pm recurrent) as distinct entities. ${ }^{[1]}$
Extramedullary solitary plasmacytoma is an uncommon presentation ${ }^{[2]}$. Plasmacytoma of skin and subcutaneous tissue is a rare tumour. Only a few cases have been reported so far ${ }^{[3,4]}$.

The majority of plasma cell neoplasms are multiple myeloma, with Solitary Plasmacytoma accounting for $6 \%$ of cases. The median age at diagnosis of Solitary Plasmacytoma is 55-65 years, on average about 10 years younger than patients with multiple myeloma ${ }^{[5,6,7]}$. Males are affected predominately (male:female ratio $2: 1)^{[5]}$. Multiple SP is called when more than one 
localized area of bone destruction or extramedullary tumor of clonal plasma cells present without any serum $M$ protein elevation or systemic features or organ dysfunction [8]. Plasmacytomas in the pediatric age group are rare. In multiple myeloma, abnormal plasma cells accumulate in the bone marrow, where they interfere with the production of normal blood cells. Myeloma cells also produce paraprotein, an abnormal antibody which can cause kidney problems. The tetrad of plasmacytoma incluces elevated calcium level, renal failure, anaemia and bone lesions. Neurological symptoms like headache, radicular pain, cord compression, and carpal tunnel syndrome, bone pain are the common presenting symptoms.

\section{Case Report}

A 52-year-old female reported at the Cytopathology Section of Department Of Pathology of our institute with complaints of a gradually increasing swelling over frontoparietal region of head of since 2 months [Fig. no. 1]. On examination a rounded swelling of $12 \times 11 \mathrm{~cm}$ size was noted over fronto-parietal region. It was nontender and firm in consistency with restricted mobility. No lymphadenopathy or organomegaly was present. Her complete haemogram reports were normal with normal renal function tests and absence of M-spike.

On investigations, X-ray skull was normal without any erosion or intracranial extension. Chest X-ray was also normal (fig. no.2). Rest of the skeletal survey was also normal. Bence Jones proteins were negative in urine. Informed consent was taken from the patient and FNAC was performed in the swelling. Material was aspirated and slides were prepared for final diagnosis.

\section{Materials and Methods}

FNA was done using 22-23 gauge needle attached to $20 \mathrm{ml}$ syringe and 2-3 passes were made in the swelling. Material was aspirated, 3-4 slides were prepared which were stained with Giemsa stain and then reported by experienced cytopathologists.

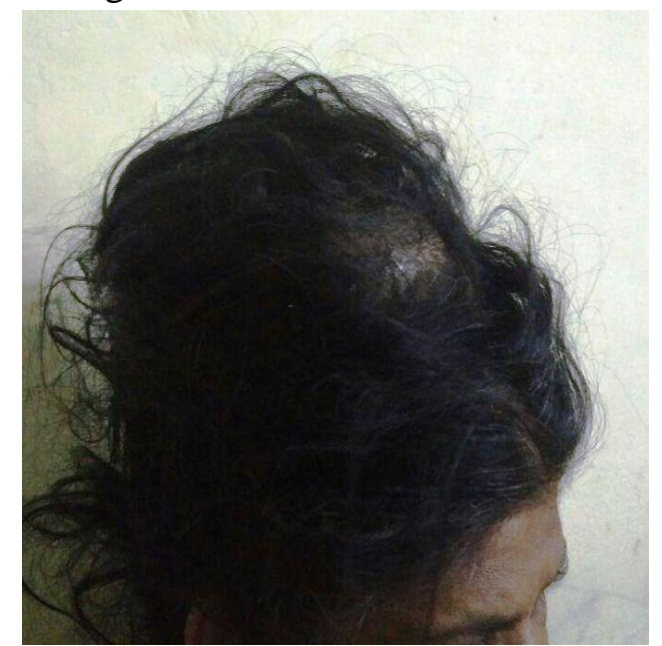

Fig no.1. A 52 year old female with scalp swelling.

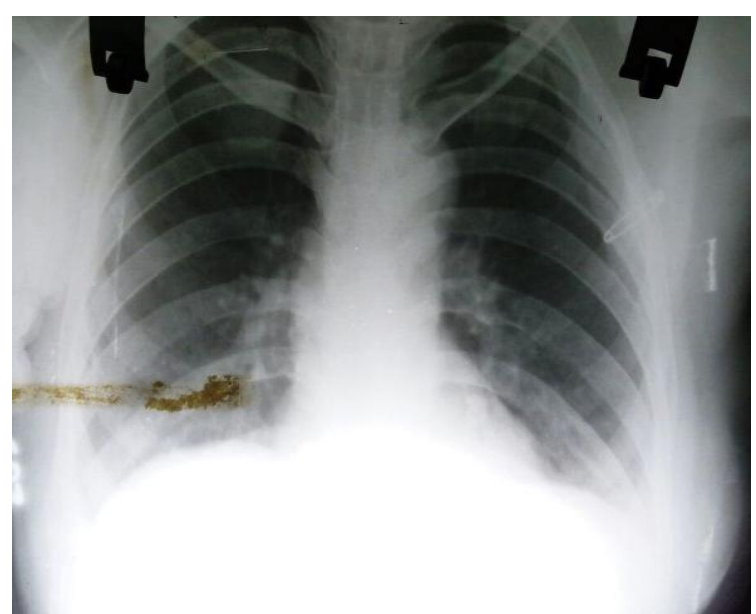

Fig. No.2. Normal Chest X-Ray Findings.

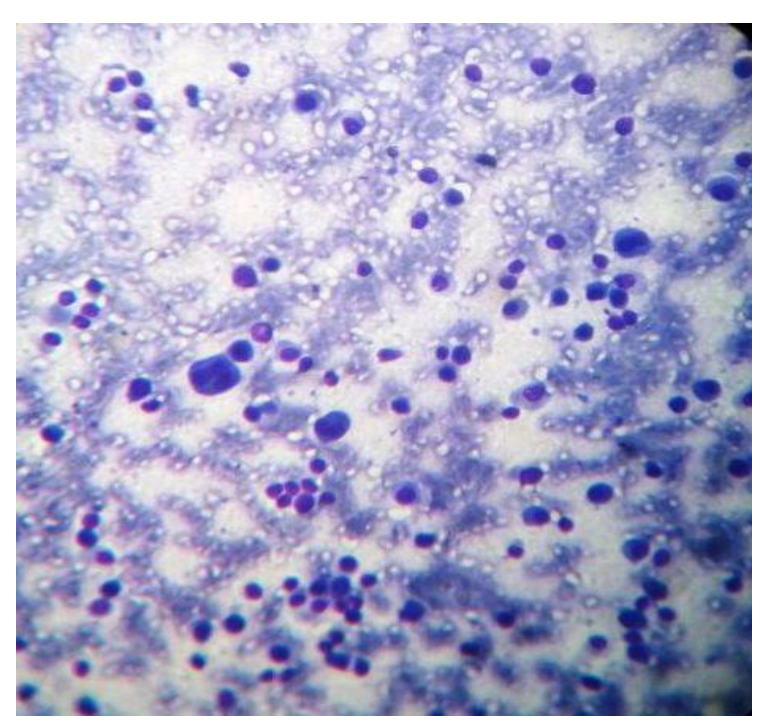

Fig no.3. Pictomicrograph Showing Plasma Cells and Binucleate Cells Against Haemorrhagic Background (40x, Giemsa stain) 


\section{Results}

The prepared smears were highly cellular showing a variable number of normal looking and atypical plasma cells including binucleate forms against a haemorrhagic background. (Fig no. 3)

\section{Discussion}

Plasmacytoma may be primary or secondary to disseminated multiple myeloma, osseous (medullary) or non-osseous (extra-medullary) in origin and solitary or multiple. While multiple myeloma is extremely rare in children accounting for less than $1 \%$ of all patients with myeloma, the incidence of solitary plasmacytomas of bones or extra-medullary plasmacytomas in the pediatric age group are even more rarely reported. Extramedullary plasmacytoma is uncommon. In head and neck region, their frequency is about $0.5 \%$. The tumour shows intense infiltration by plasma cells on histopathological examination ${ }^{[2]}$. The tumour is radiosensitive and responds to local radiotherapy ${ }^{[9]}$. Most of the patients subsequently develop the features of multiple myeloma.

Plasmacytoma of skin were reported in a series of 8 cases by Torne et al [3]. Subcutaneous plasmacytoma of breast region has also been reported ${ }^{[4]}$. Plasmacytoma of scalp is probably the rarest occurrence.

Plasma cell neoplasms are divided into multiple myelomas, solitary plasmacytomas of bone, and extramedullary plasmacytomas. Multiple myelomas represent systemic disease, solitary plasmacytomas of bone, and extramedullary plasmacytomas represent local forms of plasma cell neoplasm. The International Myeloma Working Group had proposed new criteria for the diagnosis and classification of myeloma; they have broadly divided myeloma into symptomatic myeloma, asymptomatic myeloma, and monoclonal gammopathy of undetermined significance (MGUS). According to the criteria, symptomatic myeloma requires evidence of an Mprotein in the serum and urine, bone marrow plasmacytosis, and related end-organ damage. The criteria for asymptomatic myeloma are M-protein levels $\geq 30 \mathrm{~g} / 1 \mathrm{and} /$ or bone marrow clonal cells $\geq 10 \%$, but no related organ or tissue impairment. The criteria for MGUS are M-protein levels <30 $\mathrm{g} / \mathrm{l}$ and/or bone marrow low clonal cells $<10 \%$ and no related organ or tissue impairment. Myelomarelated organ or tissue impairment adapted from International Myeloma Working Group, 2003, includes increased calcium levels, renal insufficiency, anemia, bone lesions, and other features like hyperviscosity, amyloidosis, and recurrent bacterial infections $(>2$ episodes in 12 months). ${ }^{[10,11]}$

The diagnosis of plasmacytoma is based on a radiologically solitary bone lesion, plasma cells in the biopsy specimen, fewer than $5 \%$ plasma cells in bone marrow, less than $2.0 \mathrm{~g} / \mathrm{dl}$ monoclonal protein (M-protein) in the serum when present, negative urine test for Bence Jones protein, no evidence of hyperglobulinemia and hypercalcemia, and absence of anemia ${ }^{[12]}$. Plasma cell neoplasm is radiosensitive; therefore, local debulking followed by radiotherapy had a good result on it. Once disease becomes multiple myeloma, then prognosis is not as good as plasmacytoma; chemotherapy should be added [13,14]. The potential for malignant systemic progression is higher for solitary plasmocytomas of bone than for extramedullary plasmocytomas ${ }^{[15]}$. It has been reported that extramedullary localizations of myeloma originating from the cranial bone are usually responding well to new drugs (e.g., thalidomide, bortezomib, and lenalidomide) compared to CNS myeloma ${ }^{[16]}$. It is always difficult to comment whether the brain tumor was the manifestation of multiple myeloma or a brain plasmacytoma gradually transformed into multiple myeloma.

Extracting data from plasmacytoma in the adult population, skull involving the cranial vault, skull base and the orbit and the central nervous system are rarely involved by plasma cell tumors without evidence of a plasma cell dyscrasia at another site [17].

Solitary plasmacytoma is a lesion that is often difficult to diagnose radiologically and the 
findings are often misdiagnosed as metastatic carcinoma. Positive staining with CD138 combined with negative cytokeratin staining strongly suggests plasmacytoma in cases of poorly differentiated plasmacytoma.

In our case, the tumour was subcutaneous in origin in the frontal region and was not eroding the bone. Also, there was no M-protein in the serum, no bone marrow plasmacytosis and no related end organ damage. The diagnosis was made on morphological grounds, as immunohistochemisry facility is not available in our institute. In the absence of lytic lesions at other sites, it would be appropriate to tail that our case is a solitary extramedullary plasmacytoma of scalp without any bony erosion on the skull bone.

Fine needle aspiration cytology smears stained with giemsa has been chosen as the first line of investigation in this case which proved very helpful in the diagnosis as the clinical and radiological findings were non-contributory.

\section{Conclusion}

Cases of plasmacytoma should be on lifelong regular follow up, as it has a tendency to progress into multiple myeloma. Help of hematologist should be taken to differentiate plasmacytoma from multiple myeloma, as treatment modality differs from one another. FNAC should be the first line of investigation in any suspected swelling as it is a rapid, cost-effective outpatient (OPD) procedure that helps in the diagnosis of rare cases like this when they might mimic as a completely different entity clinically.

\section{References}

1. International Myeloma Working Group. Criteria for the classification of monoclenal gammopathies, multiple myeloma and related disorders: A report of the International Myeloma Working Group. Br J Haematol 2003;121:749-57. [PUBMED]

\section{Anderson}

PE.

Extramedullary plasmacytomas. Acta Radiol (Stock) 1949; 32:365-374.

3. Torne R, Su WPD, Winkelmann RK. Clinicopathologic study of cutaneous plasmacytoma. Int J Dermatol 1990; 29:562-566.

4. Marino MJ. Plasmacytoma of the breast. Arch Pathol Lab Med 1984; 108:676678.

5. Ozsahin $\mathrm{M}$, Tsang RW, Poortmans $\mathrm{P}$, Belkacémi Y, Bolla M, Dinçbas FO, et al. Outcomes and patterns of failure in solitary plasmacytoma: A multicenter rare cancer network study of 258 patients. Int $\mathbf{J}$ Radiat Oncol Biol Phys 2006;64:210-7.

6. Strojan P, Soba E, Lamovec J, Munda A. Extramedullary plasmacytoma: Clinical and histopathologic study. Int $\mathrm{J}$ Radiat Oncol Biol Phys 2002;53:692-701. [PUBMED]

7. Tsang RW, Gospodarowicz MK, Pintilie M, Bezjak A, Wells W, Hodgson DC, et al. Solitary plasmacytoma treated with radiotherapy: Impact of tumor size on outcome. Int $\mathbf{J}$ Radiat Oncol Biol Phys 2001;50:113-20. [PUBMED]

8. Dincer C, Baskaya M, Yucer N. Solitary intracranial plasmacytoma in a child. Report of a 7-year-old girl. Turkish Neurosurg 1994;4:47-50.

9. Mayr NA, Wen BC, Hussey DH. The role of radiation therapy in treatment of solitary plasmacytoma. Radiother Oncol 1990; 17:293-303.

10. International Myeloma Working Group: Criteria for the classification of monoclonal gammopathies, multiple myeloma and related disorders: A report of the International Myeloma Working Group. Br J Haematol 2003;121:749-57.

11. BCSH and UKMF Guidelines on the Management and Diagnosis of Multiple Myeloma Sept 2010. 14/10/2010. 
12. Tanaka M, Shibui S, Nomura K, Nakanishi Y. Solitary plasmacytoma of the skull: A case report. Jpn J Clin Oncol 1998;28:62630.

13. Engelsma RJ, De Bree R, Janssen JJ, Scheeren RA. Plasmacytoma of the mastoid bone: Solitary and systemic. J Laryngol Otol 2000;114:378-80.

14. Lorsbach RB, Hsi ED, Dogan A, Fend F. Plasma cell myeloma and related neoplasms. Am J Clin Pathol 2011;136:168-82.

15. Reyhan M, Tercan F, Ergin M, Sukan, Aydin M, Yapar AF. Sonographic diagnosis of a tracheal extramedullary plasmacytoma. J Ultrasound Med 2005;24:1031-4.

16. Gozzetti A, Cerase A, Lotti F, Rossi D, Palumbo A, Petrucci MT, et al. Extramedullary intracranial localization of multiple myeloma and treatment with novel agents: A retrospective survey of 50 patients. Cancer 2012;118:1574-84.

17. Dimopoulos MA, Moulopoulos A, Delasalle K, Alexanian R. Solitary plasmacytoma of bone and asymptomatic multiple myeloma. Hematol Oncol Clin North Am 1992;6:359-69. [PUBMED]. 